Article

\title{
Hinduism in India and Congregational Forms: Influences of Modernization and Social Networks
}

\author{
Samuel Stroope \\ Department of Sociology, Baylor University, One Bear Place \#97326, Waco, TX 76798-7326, USA; \\ E-Mail: sam_stroope@baylor.edu; Tel.: +1-254-710-4578; Fax: +1-254-710-1175
}

Received: 30 October 2011 / Accepted: 2 December 2011 / Published: 8 December 2011

\begin{abstract}
In light of increased scholarly interest in the scientific study of non-Christian religions and societies, I review sociological research on Hinduism. Specifically, I focus on Hindu congregational forms, a phenomenon noted in social scientific literature. Drawing on existing theories from the sociology of religion, this article illuminates possible social sources of Hindu congregational forms. Two preliminary sources are proposed and possible mechanisms elaborated: (1) modernization and (2) social networks. I conclude by proposing several new directions for research on Hindu congregational forms. These arguments and proposals offer directions for expanding understanding of how theories in the sociology of religion might operate beyond Christianity and the West.
\end{abstract}

Keywords: India; Hinduism; congregations; organizations; satsang; modernization; institutional differentiation; rationalization; social networks; social embeddedness

\section{Introduction}

Does congregational religion exist in Indian Hinduism? ${ }^{1}$ If so, what are the social sources of Hindu congregational participation? Primers on Hinduism in India report that Hindu religious behavior typically consists of religious acts at temples, household shrines, and other sacred and ordinary places [1-5]. Common Hindu religious acts include prayer, conjoint sight of devotee and god (darshan), and various ritual practices. Popular ritual practices include, but are not limited to, meditations (e.g., yoga), service (e.g., seva, puja), festivals, pilgrimages, sacrifices, and domestic rituals [6]. Although Hindu

\footnotetext{
1 I derive the term "congregational religion" from sociologists' analysis of Christianity but use the term in a more general sense in this article.
} 
religious practice is often embedded within communitarian social contexts such as extended family and caste, there is a great deal of individualism in Hindu religious practice. Hindus may engage in sacred acts in settings where other lay devotees are present, but significant regular social interaction with fellow lay devotees is usually not a necessary or central component of Hindu religious practice. ${ }^{2}$ Sociologists of religion have described individualistic styles of religious behavior as noncongregational religion. ${ }^{3}$ Noncongregational religion is understood to be anomalous or incipient in Western societies [9-15], though noncongregational religious expressions are normative in many non-Christian societies such as India [5]. Many non-Christian Asian societies and communities do not place emphasis on congregational forms [16], though these are hallmarks of Christianity-historically the primary focus of sociologists of religion [17].

Despite generalizations that religious practice in non-Christian non-western societies are not usually congregational in style, there are reasons to expect congregational forms to develop. This paper focuses on congregational forms in settings where noncongregational religion is normative. Specifically, I focus on congregational forms in Indian Hinduism, congregational participation among Hindus, and suggest possible sources of their development and Hindus' involvement in them. This article specifically builds the sociology of Hinduism literature by highlighting insights from diaspora research and elaborating the interaction of impacts from modernization and the role of social networks. The sociological study of non-western and non-Christian forms of religious practice-especially in major religions such as Hinduism and countries such as India-provide broader arenas for the refinement of theory in the sociology of religion and the development of empirical expectations.

\section{Background}

India is a drama of immense religious variation both between religious traditions in India and within Hinduism itself. In fact, some Hinduism scholars argue that there is just as much variation found between religious streams within Hinduism as found between major world religions such as Christianity, Islam, and Judaism [18]. King [19] argues that: "[Hinduism] is often presented in a onedimensional manner, giving the impression of an overall unity and coherence which this religious tradition never possessed. The various historical strands which went into the making of Hinduism include a great diversity of beliefs, rituals, and institutions which, strictly speaking, are often not comparable to those found elsewhere. The concept 'Hinduism' itself is such a wide umbrella-term as to be heuristically almost useless for analysis.” At the least, to see Hinduism as a monolithic religion

2 India researchers will appreciate that any generalizations about Hinduism will fail in some sense due to the enormous variety of religious life that proceeds under the banner of Hinduism in India across different regions, castes, and time periods [7]. Nevertheless, the brief introductory comments provided here serve to orient general readers and comports with similar efforts by India scholars to give a sense of Hindu religious life, especially along the lines that it differs from Abrahamic religions such as Christianity.

3 While the sociology of religion literature often refers to noncongregational religious expressions as "unchurched religion" [8], this terminology is less appropriate for non-Christian religions and so this article uses the term "noncongregational religion." 
would be a flawed assumption. It is important to note Hinduism's expansive internal diversity when considering noncongregational as well as congregational Hindu religiosity. ${ }^{4}$

\subsection{Hinduism}

In some ways, relative to the size and complexity of Hinduism in India, there exists a great need for additional scholarly attention devoted to the sociology of Hinduism in India [23]. While there exists a rich social anthropological literature surrounding Hinduism [for an overview, see 24], this foundational work could be complemented by bringing the insights of this literature into deeper conversation with recent theories and concepts developed among sociologists of religion outside of India, including those who study the Indian diaspora. Also, more could be done to synthesize insights and develop testable hypotheses for use in quantitative analysis [25]. This represents a step toward addressing the gap in quantitative sociological research on Hindu religious practice using nationally representative data sets that remains [26]. Considering research on the Hindu diaspora, the population of the diaspora is small in comparison to the population of Hindus in India, but considerable qualitative and quantitative sociological attention has been devoted to diasporic Hindu religion relative to its size. It is also in this immigrant religion literature that we find reports of strong Hindu congregational forms. These forms are by no means widely normative for Hindus in most contexts. In recent qualitative research among U.S. Hindus, a respondent noted that: “...Christians have the church as a support group, Hindus don't have anything" [27]. While it may generally be the case that Hindus tend not to form voluntary religious congregations, there are, however, exceptions to this generalization both in immigrant contexts [5,28,29], as well as in India [4,23].

\subsection{Diaspora Hindus}

Non-Christian immigrant groups in the United States, such as Hindus and Buddhists, are typically thought of as noncongregational in their style of religiosity. Cadge and Ecklund [30] find that nonChristian new immigrants to the United States, specifically Hindus and Buddhists, are less likely to attend corporate worship gatherings than Christian immigrants. The reasons for low non-Christian corporate worship gathering attendance are not well documented, but Cadge and Ecklund posit two possible reasons: (1) Non-Christians attend these gatherings less because weekly corporate gathering is not a norm in their religious tradition. (2) Hindu and Buddhist temples and religious worship centers are in sparse supply in the U.S. as compared with the abundance of Christian houses of worship (even if a Hindu in the U.S. wished to attend weekly worship gatherings, there are likely none available in the immediate vicinity because Indians are the most geographically dispersed ethnic minority in the U.S.). However, non-Christian immigrants of traditionally noncongregational religions have been observed to exhibit incipient and even elaborate congregational practice as they seek to perpetuate

4 Lorenzen (1999) provides a review of the invented Hinduism discussion. He argues for an eighteenth century Indian use of "Hinduism," and suggests a nascent unifying Hindu religious identity as early as 300 to 600 C.E. In contrast, many scholars point to a nineteenth century invention of the term "Hinduism" by British administrators to describe the diverse religious life that before that time had no overarching unity [20-22]. Lipner [7] favors the beginning use of "Hindu" as a cultural rather than "specifically religious" term and warns that accepting a religious essentialist understanding of Hinduism, among other dangers, leads to "undercutting the rich diversity of actual belief and practice." 
culture and adjust to the host country. Immigrant communities in the United States emulate American Protestant congregational forms in voluntary membership, lay leadership, expansion of services, organizational networks, ritual, worship times and format, clergy roles, and language [29,31,32]. These adaptations take place even among Hindus, Buddhists, and Parsis in the U.S. context, despite the fact that congregational forms are relatively rare among homeland co-religionists.

Regarding Hindus, Kurien [27] documents two tight-knit "subethnic organizations" among South Indians in the United States, the satsang and the bala vihar. Lay congregations such as these, as well as congregation-like temples, are used by Hindus in order to: gain legitimization, garner participation, re-create Hindu environments that transmit values to Hindu adults and children, and build social support among co-religionists [27]. Increasingly religious-oriented ethnic media is also used within these processes to awaken religiosity among Indians and their children in the United States [33].

Yang and Ebaugh [29] reason that "immigrant religious communities in the United States are in a powerful position to exert influence in their countries of origin," including increasing the use of congregational forms. This position is particularly relevant for Hindus since second-generation Hindus may be more transnational than other immigrant religionists [34]. Kurien suggests precisely this notion, that diaspora congregations are playing a part in the increased popularity of congregations in India [5]. Yang and Ebaugh [29] stress the need for "further research in the immigrant home countries and other parts of the world." Such transnational research is of increasing importance considering religion's increasingly less confined situation due to shrinking barriers of time and physical distances [35]. Whether or not a new backward flow or revitalization of congregational religion from West to East is emerging, though critical, is beyond the scope of this paper. We must however take into account observations from diasporic Hindu congregations and consider it as one possible influence toward the existence of congregational Hinduism in India. Are there others that predate major international Hindu migration?

Congregational forms have been present in Indian immigrants' homeland in recent centuries, though the degree of foreign impetus for these structures is debated [36]. The Brahmo Samaj, a Hindu reform movement in nineteenth century Bengal, developed "patterns of worship on the model provided in the Protestant churches" [19]. Shah [23] records congregational tendencies among sectarian Hindus in the last 200 years as well as well as recent times, proposing a general increase in the phenomenon. Others conjecture that there has been an increase in these congregation-styled groups in recent decades [5].

\subsection{Hindu Congregational Religion in India}

In prior research, Hertel [37] explores the congregational nature of temples in North India. Hertel defines a congregation as a "well-defined body of people who share the same priest(s) for purposes of worship and / or for performance of rites of passage. Congregations are membership groups within churches and sects [37]. Four types of Hindu congregations are delineated, two of which are local temple congregations and temples with occasionally gathered satellite laity. Recognizing the ethnocentricity in only considering those groups congregations that have weekly meetings, Hertel extends the concept of the congregation to non-western religious life by jettisoning any particular units of time between meetings. He anchors his definition of a congregation to a body of people that meets 
with priests. Although helpful in building a foundation for the recognition of the congregation in Hindu religious life, the principle of priest interaction is not broad enough when taking into account the intimate Hindu religious groups that have no professional clergy (see Shah 2006). In this way only Hertel's concept of "membership groups" is a sufficiently flexible building block in constructing a guiding definition in the study of Hindu congregations.

More recently, sociologists of religion have developed specific definitions of religious congregations. Chaves [38] defines religious congregations as: "relatively small-scale, local collectivities and organizations through which people routinely engage in religious activity: churches, synagogues, mosques, temples." Stark et al. [13] describe the boundaries of congregational religion by delineating churched and what he refers to as "unchurched religion," but what in this article is referred to as noncongregational religion:

Although all religions are social, there is substantial variation in their organizational character so that some can be identified as 'churches', while others fall far short of any legitimate definition of that term. A churched religion has a relatively stable, organized congregation of lay members who acknowledge a specific religious creed - therefore, we include both 'sects' and 'churches' in churched religions. An unchurched religion typically lacks a congregational life, usually existing as relatively free-floating culture based on loose networks of likeminded individuals who, if they do gather regularly, do not acknowledge a specific religious creed, although they may tend to share a common religious outlook. Unchurched religions may or may not coalesce around leaders.

Essentially, Stark et al. [13] see congregations as "groups of adherents who meet regularly for religious reasons." The above definitions center on routine, small religious gatherings of members.

Although noncongregational religion represents the majority of Hindu religious behavior, this is by no means the case for all Hindus in India. Congregational activity is normative among some Hindu sects. Sectarian Hinduism generally has "exclusive social boundaries" and aspects such as each sect having its own sacred literature, elaborate social organization, restrictions on religious participation outside the sect, and variances in entirely ascetic or lay leadership:

At the neighborhood level the lay members form groups such as satsang, bhajan or kirtan mandal. They often organize festivals and pilgrimages. Frequent interactions among followers lead to the formation of strong friendships. In arranged marriages, preference is give to members of the sect, and it has become common to mention this preference in matrimonial advertisements. Members of every sect now form associations at local, regional, national and international levels. There are also special associations of their women, youth, and senior citizens. [23]

Emotionality, music, worship ceremonies, and ritual food associated with Hindu congregations of sectarian or non-sectarian devotees:

The devotees who gather together to worship by chanting bhajans or hymns are usually, but not necessarily, affiliated to a sect. The chanting, the music, the rhythm and the atmosphere of fervent devotion can produce a deep effect and some enter a state of trance. At these gatherings there is also sometimes an arati ceremony and the distribution of prasada. Groups who gather together in this way to worship through hymn-singing occur all over India and at most levels of society. [4] 
Singer [39] analyzes the influence of modernization on Hindu religion. In his fieldwork in Tamil Nadu, in southern India, in the 1950s and 60s Singer encountered bhajana groups. Bhajana refers to a kind of prayer or devotional hymn sung within these congregational groups. Similarly, in modern satsangs participants often refer to their devotional songs as bhajans. Singer [39] gives a picture of the historical linkages and modern innovations of the bhajana congregations:

In Madras City a form of congregational devotional worship - called bhajana-is becoming popular and seems to be developing into a Hindu cult that links the cults of temple and domestic worship. Superficially, the bhajanas resemble the older devotional cults (bhakti) within Hinduism, emphasizing recitation of divine names and worship of personal deities. But the contemporary bhajanas show many features that are distinctive of the region within which they have developed, of the social groups that support the development, and of the problems confronting contemporary Hinduism as it tries to adapt itself to modern urban conditions. ... Since the end of World War II, bhajana groups have multiplied rapidly in the city and have also become fashionable in smaller towns and villages. The meeting of a bhajana group usually takes place at a private home and is attended by a mixture of castes and sects, with middle-class professionals and Smarta Brahmans predominating.

These bhajanas gather with varied frequency. The weekly type is the most intimate, local, and common:

an evening gathering of relatives, friends, and neighbors in a private home for about three hours from 7:30 to 10:30 P.M.; Saturday night is the most popular choice, although some groups meet on Thursday or other nights of the week. The men of the group, usually about a dozen, sit in a circle or in rows on the floor and lead the singing, while the women and children sit to one side and join in the refrains. [39]

Though Singer found significant religious continuity in people's cultural and family backgrounds, there was also discontinuity and innovation. Along with individuals' ishtadevata (freedom to choose a personal deity), relative flexibility and innovation is latent in Hindu religious life. We should not be surprised by innovative reactions, adaptations, and competition with the forces of modernization. Singer's [39] bhajanas drew heavily from a caste with roots in ritual tradition yet: "they have felt the need to develop Krishna bhakti as an 'easier path to salvation,' since their middle-class and professional occupations, their Westernized education, and their increasing secularism have made the older and more difficult paths less accessible to them." Might there be numerous instances around India of modernizing forces drawing publics toward devotional Hinduism, including congregational forms?

Singer [39] proposes reasons for the bhajanas' development: fostering community in mass urban society, noblesse oblige, gaining local reputation, garnering spiritual merit, the Hindu bhakti (devotional) tradition, and following scriptural sanction. Finding scriptural rationale for contemporary innovation is similar to observations of religious strategies in immigrant contexts. Immigrants see their religious adaptations to new settings as returning to forgotten orthodoxies [29]. Not only are Singer's bhajanas groups of modernizing Hindus finding orthodox rationales for their adaptive needs in new conditions, but they are perhaps religious groups in competition with modernizing and westernizing forces. In more recent times these congregational developments could partially be a result of homeward diasporic influence [5]. Growth in the popularity of Hindu congregations in India may also 
be because they are fulfilling religious enclave functions similar to those in the diaspora context, but doing so in India - a society undergoing large scale modernization and cultural change.

Singer's bhajanas also mirror societal developments toward reducing communal and regional divisions. In this way, they are in continuity with elements of modernization, or they are at least a way of reconciling the worlds of fervent religion and modernization. They function as a vehicle for the adaption of devout Hindu religious life amid modernizing forces.

To be clear, in Hindu congregations (particularly Singer's bhajanas, but also many diasporic satsang accounts) we do not merely see fluid temporary associations, but rather informal organic congregations that often develop into more elaborate and formalized structures with financial accounts, social service projects, classes, citywide networks, and large scale festivals. Though often organic and varied in practice and leadership, these groups have the precedent of continuity, perpetuation, and formal organization largely accomplished by lay leaders who have other work and family demands on their time.

In this paper, congregations are understood, not as necessarily weekly meetings led by priests or groups with membership rosters and doctrinal statements, but rather social gatherings where lay worshippers interact with each other around religious belief and practice, with or without professional leaders. As cited by Shah [23], among the many religious gatherings that can be observed, satsang is a form of congregation found among sectarian and nonsectarian Hindus in India. In satsang there can be regular, scheduled worship and social interaction with fellow lay religionists, assigned leaders and organizers, but without necessarily a formal creedal document or necessarily other elements of an elaborate congregational life. ${ }^{5}$

\subsection{Modernization and Congregational Forms}

Indian scholars have noted that one of the impacts modernization is to cultivate "radical and lasting changes in Indian society and culture," stemming from "new technology, institutions, knowledge, beliefs and values" [40]. These causal sources of change can be grouped under two processes highlighted in the international sociology of religion literature: (1) institutional differentiation, and (2) rationalization. ${ }^{6}$ Below I draw connections between these two sources and congregational forms.

5 See Shah [23] for a description of congregational practices and group boundaries of sectarian Hinduism in India, and sects' growth.

6 In the thinking of eminent Indian social anthropologist M.N. Srinivas, these influences of modernization might best be labeled as Westernization. Another major source of social change in Indian civilization highlighted by Srinivas is Sanskritization, described by many as the "single most important contribution to social science scholarship from India" [25,41]. Srinivas [40,42] developed the idea that low castes "took over, as far as possible, the customs, rites and beliefs of the Brahmins," or embraced high status religious practices for the sake of manipulating their ritual standing and facilitating social mobility. Srinivas also suggested that Sanskritization may be at odds with Westernization. Caste structure is an important topic outside the scope of the main focus of this article. Suffice it to say that regions in India with strong anti-caste movements should be those where processes of Sanskritization have weaker sway [43]. It may also be the case that areas where high caste persons feel their traditional status under greater threat due to egalitarian elements of modernization are precisely those areas where high caste Hindus utilize the boundedness and potential exclusivity of congregational forms as a way to cope with and buffer change [for an extended discussion, see 26]. 
A major way that modernization impacts religion is through institutional differentiation. Sociologists note that religion is frequently tied to kinship, regional location, and national identity [44]. This is especially true in developing agrarian societies such as India where society's various social institutions are thoroughly infused with religion such that it is difficult to separate out religion from cultural elements in society for example $[40,45]$. In other words, religion is not necessarily clustered in a distinct sector of social life but has considerable entwinement with other life spheres. One way modernization impacts religion is by more fully dividing society into specialized spheres and multiply organizational forms and units within spheres [44]. This way of conceiving of institutional differentiation as one of the ways that modernization impacts religion follows a considerable literature in the sociology of religion [46]. The differentiation of society and the desacralization of social institutions are processes that sociologists of religion have analyzed in various contexts around the world, including outside of Christianity [47,48]. Contemporary modernization theorists in the sociology of religion generally hold that religion does not necessarily die or decline in modernity, but that it transforms in modernity [49]. In drawing from developments in modernity, these theorists do not look mainly to modernizing processes such as urbanization or industrialization, but rather the separation of various social institutions from religion as part of a larger pattern of institutional differentiation in modernity [49]. Religion becomes increasingly distinct from other social institutions such as the state, the market, education, the polity, the family, and the mass media. Part of what this differentiation does is open up religious freedom and religious choice. One religious group cannot use (or cannot as easily) use the force of the state to coerce religious groups or people in their religious choices or style of religious practice. This situation invites religious pluralism and in such an environment religious innovators or entrepreneurs are subject to less state and societal coercion; they may organize, meet, teach, and recruit from the public with greater freedom.

Another major way that modernization impacts religion is through rationalization. At the organizational level, rationalization is seen in the way that interpersonal relationships are more bureaucratic and less formal, seen in view of science, and are linked through technology. For example, religious groups come increasingly to rely on pre-determined policies to handle disputes or leadership succession rather than through less formal means. Rationalization also deals with science. Science in many instances claims increasingly broader areas of life as the subject of its explanations that may have been previously the domain of religion. In this way science competes with religion. The effects of a Tsunami in the coastal areas of Tamil Nadu can be explained with reference to tectonic plate shifts with no reference to a supernatural realm. But science also takes as its subject humans and their behavior. Patterns of religious involvement and the provision of material resources to religious groups can be explained and influenced through the use of scientific theories and the manipulation of physical spaces and organizational forms. The role of the supernatural in the human behavior is limited or at least transformed through such modernized forms of thinking [46]. In fact recent influential ethnographies of urban religiosity in India turn on this issue, discussing it under the heading of "disenchantment" [50].

While it is difficult to determine whether Hinduism is becoming more distinct from other social institutions in India or whether Hinduism is becoming more organizational in character, it is possible that the presence and efforts of Hindu organizations and their use of the congregational formats are a religious response to modernization. It is possible that religious groups in the religious marketplace are 
responding to the presence of new competitors in their midst. Various spheres of society undergoing differentiation from other spheres, including religion, come to follow their own logics and interests. Since these spheres are less entwined with religion, these spheres are free to critique or compete against religion. The mass media is one example, as are various forms of entertainment and carousing scenes and lifestyle enclaves such as those surrounding night clubs. Youth scenes in India's metro areas and large cities also serve as an example. Compared to many advanced industrial nations where religion appears to have undergone considerable marginalization [16], India's modernization might appear mild. However, in a society as religiously saturated and integrated as India, signs of differentiation would be noticeable and troubling to many religiously devout Hindus. It should be no surprise that creative religious responses to the competitor of modernization might appear on the Indian landscape.

We can look to several examples of creative Hindu competition amid modernization in India. Burger [51] observes the trademarks, brandings, and consumer benefits of yoga as an Indian spiritual export product on the global religious market. Focusing on the religious consumption narratives of devotees, Warrier [52] reveals the competition between India's proliferating gurus, promoting their diverse religious wares on the Indian and global religious market. Technology, the ease of global dissemination, and a newly moneyed urban middle-class are resulting in "multiple choices in every sphere of life, including that of religion," thus cultivating a vigorous spiritual marketplace [52]. As one example of why Hindu organizations might utilize the boundedness and membership of congregational forms, organizations might see an emerging Indian middle class and seek to tap into this growing religious niche and its social and material resources [52]. Congregation-like characteristics, such as exclusivism, are visible in some sectors of Indian Hinduism. Though allowing for the "vastly diverse range of beliefs, practices, and movements" and the foreign origin and imposition of the term "Hinduism" as a surface level "conceptual unity" on Indian religious phenomena, some sociologists of religion still assume a basic congregationless and nonexclusive uniformity within Hinduism [53]. As reviewed above in this article, other scholars have outlined the increase of stricter sectarian Hinduism in the last 200 years [23]. These Hindu sects function in many ways as exclusive religious bodies utilizing congregational forms, exclusivist religious participation, exclusive social bonds, particularistic sacred literature, and in some cases entirely lay leadership [23,39]. Ethnographic findings support such distinctions. For instance, in the realm of guru-centered Hinduism, Warrier [52] proposes two main "guru orientations," the inclusivist "tourist of gurus" and the exclusivist devotee:

In terms of being "attached to a guru, however, [the exclusivists] remain exclusively loyal to their chosen one. Only in extreme circumstances, such as the passing away of the chosen guru or disillusionment with him or her, will exclusivists consider the option of attachment to a new spiritual mentor.

Exclusivity is not uncommon even in the fluid world of Hindu guru devotion. Characterization of Hindu religious life as uniformly non-exclusive and non-congregational is not compelling in view of such modern Hindu phenomena.

An additional religious response to the competitor of modernization in India can be seen in the energetic activity of Hindu revivalist organizations. Some of these organizations are exclusivistic and congregational. The arguments outlined above suggest that revivalist organizations may emerge and act out of a response to modernization. The religiously devout might see that old cultural constraints 
are not holding people to the religion and traditions of their families and backgrounds because secular activities and sentiments are competing with religious devotion. They might see the need to actively compete with perceived competition stemming from modernization processes. In this way, the effects of modernization are moderated by the power of tradition, an issue examined in the social anthropological literature on Hinduism. ${ }^{7}$ Similar to the interaction of tradition and social change seen in the religious adaptations of the Hindu diaspora, congregational forms may be useful for creating enclaves of nostalgic religious purity, reconstituting orthodoxy, and transmitting religious tradition to the next generation [5,33,54]. In these ways, the use of congregational forms by Hindus in India may represent the kinds of "innovative returns to tradition" seen in other parts of the world [55].

\subsection{Social Networks and Congregational Forms}

As a religious response to modernization, Hindu involvement in congregational forms turns on the benefits of religious social networks and the influence of religious social networks. Religious congregations that are comprised of regular gatherings of the same people often serve as a powerful form of social support in the face of a sense of uncertainty, a sense of rootlessness, and lack of social ties, characteristics of people in societies undergoing modernization [16,56,57]. However, participating in new religious activities, such as involvement in somewhat novel congregational forms, involves a certain level of risk and uncertainty in and of itself (Elster 1986). The bonds of trust found in preexisting social networks, however, have been shown to smooth the path toward changes in religious behaviors and tastes [58-61]. The influence of social networks on changes in religious behavior may come in the form of direct constraints on behavior, or it may take place through fostering new behavior-guiding religious tastes [62]. For example, people's uncertainties about religious activities may be reduced by the testimony of trusted others and people may also adopt religious practices to avoid social penalties from others $[63,64]$. It is also important to keep in mind that the religious organization or group has an interest in reducing risk. The religious organization may reason that known persons already in their social networks are safer to recruit [65], and they may exert considerable energy and rely heavily on social bonds in recruiting and retaining such people in their religious activities.

Members of religious social networks may be influenced by a religious organization or they may be motivated by immediate family members, extended relatives, friends, or other social relations who might introduce opportunities to participate in novel congregational groups or even apply pressure to that end. Some people may reason that if their social network of peers is participating in a religious congregation then they should also. They may be motivated by pleasing others or gaining social rewards such as maintaining a reputation among peers [63,64]. Many aspects of sociological theories of religion that have been developed in Western and Christian contexts take for granted that the individual (regardless of his or her age or position in the social structure) is the one who makes decisions about his or her religious behavior. In many non-Western contexts such as India, it is other people in society, especially in the family (e.g., the husband or senior male or female in the

This view can be categorized under the idea that tradition coexists with modernity in India, one of three approaches to tradition and modernity in India (the other two being: [1] modernity destroys tradition, and [2] tradition will prevent modernization [for a review of social science literature on tradition and modernization in India, see 25,39]. 
household), who makes many decisions for others, including religious decisions. At the least, the religious actor is under the consistent gaze of senior family members as a form of social influence. The issue of social constraints on religious tastes and choices [62] become critical when theorizing the social sources of Hindu congregational participation in the Indian context.

Social networks may operate as an influence toward satsang participation, for example. Traditional Hindu housewives may have additional religious motives for a wide array of religious fasts, rituals, and activities (including satsang) that may be above and beyond other people's religious investments. It is sometimes believed that wives' religious activities can gain merit and advantage the rest of the family in their health, lives, and pursuits [66,67]. Single women may similarly participate in religious activities in order to further their own concerns such as education or marriage [5]. Many respondents said they participate in satsang because of a sense of peace they feel during the gathering and for a time afterwards, a capability for dealing with life's challenges that is often facilitated in the context of social networks [68].

\section{Discussion}

A sociological literature on the religious lives of immigrants has documented how immigrants use religious congregational forms for ethnic formation, transmission of traditional values, protection from outside influences, social support and other goals regarding coping and adaptation to social change. In this article, I have tried to advance our understanding of how Hindus in India may use congregational forms in ways similar to immigrant religious communities. This paper sheds new light on the literature on the sociology of religion in India by considering how social developments fostered by modernization, such as rationalization and institutional differentiation might foster Hindu congregational forms. The arguments presented here suggest that Hindu groups may respond congregationally to impacts from modernization because congregational forms serve as effective buffers to outside competition and serve as effective receptacles for Hindus experiencing new levels of individual choice in the Indian religious market. I also bring into relief the importance of social networks in understanding the appeal of congregations, especially social support, and the processes by which individuals involve themselves in novel congregational forms. Specifically, the social embeddedness of religious choices comes to take on particular importance in India because people other than the religious actor, especially senior family members, have considerable influence on decisions for the individual, including religious decisions.

Insights from the social anthropological literature on religion in India give reason to believe that such changes in Hindu religious expression should be expected. In the diverse religious marketplace of contemporary India, it is not unreasonable to expect innovative responses as religious persons and groups face social change and cultural competitors, perceived or real. There are historical examples of such religious innovation. Sectors of Hindu religion in India underwent changes in the nineteenth century in response to Protestant congregations in West Bengal [19]. Some have argued that the emergence of Hinduism as a unifying religious identity - a "world religion"- has been an outgrowth of a religious response to British orientalism in the nineteenth century [69]. Similar innovations might be going on in our time through the use of congregational forms by Hindu denominations, sects [23], and innovative revivalist organizations [70]. The use of congregational forms can be seen as responses 
to or the product of modernizing processes in India. We can envision various examples. Particular sects may see this as an opportunity to promote the expansion of their particular expression of Hinduism. Such organizations may leverage family and peer networks to shore up their recruitment. On the other hand, family, peer networks, and individual religious devotees themselves may have their own motivations, using their bonds of trust, credible testimony, and social pressure to assemble themselves and others into Hindu congregations.

Regarding the role of modernization and social networks in Hindu congregational forms, several potentially fruitful avenues of further inquiry present themselves. Further research should examine the degree to which the use of congregations by religious Hindus are innovative strategies for facilitating, adapting to, and competing with modernizing forces in contemporary India: differentiation, urbanization, international migration, increasing geographic mobility within India, waning of the salience of caste boundaries, and a growing differentiation and marginalization of religious traditions, particularly among emerging generations. The new wealth and opportunities of the India's middle class and changes in household structures and gender roles in urban India may also play roles [71]. Further research should also consider continuities between diasporic and homeland congregations, especially as a kind of cooperative transmission of religion and culture to children when any one child's parents cannot take on all of the transmission responsibilities. Along these lines, the participation of children and youth in these congregations should be compared in homeland and diaspora settings. Following the work of Singer [39], different kinds of satsang congregations should be categorized, and more light should be shed on their formalization trajectories, networked associations, and overall prevalence. This research should be conducted on an even more transsectarian and trans-regional level.

Social networks may also play an important role among both sectarian congregations as well as nonsectarian Hindus who utilize Hindu congregational forms such as the satsang. Social networks' various ways of directly or indirectly influencing individuals' styles of religious participation are documented in theorizing and qualitative research on religious recruitment and religious switching. One area for future research is to help sort out the degree to which congregational participation is due to direct social influence on participation or indirect social influences on changes in individuals' participation-guiding religious tastes [62]. The attractiveness of these congregations can be seen in the ethnic church functions described in immigrant religion literature as well as anthropological work in India [39].

Subsequent research directions, as introduced above, could also include investigations of relationships between social networks and specific forms of congregational participation such as satsang participation. Such research would serve to better understand how the role of recommendation, trust, recruitment, or other direct and indirect social network factors might be differently attributed to various forms of congregational participation. Collecting religion survey data on India would help systematically compare evidence for these various social influences as well as help estimate the pervasiveness of congregational forms in Hindu religious life. At present, scant quantitative religion data on India exists. The various consequences of Hindu congregational involvement is also an area needing future research. For example, Singer [39] suggests that Hindu congregational groups have the effect of smoothing inter-caste relations in the workplace and other settings outside of the groups themselves, but the religious and demographic composition of the congregations themselves should be 
examined as a potentially important moderating factor [72,73]. Comparative analysis of satsang attendance between different regions of India and the various diasporic communities along all of the above avenues for research may expand our understanding of how the broader societal context shapes Hindu congregations.

Other more speculative sources of Hindu congregational forms may also prove worthy of study: mass movement toward bhakti Hinduism, responses to British colonial influences, and the influence of the Hindu diaspora back on religious life in the homeland in a time of increasing transnationalism. The diaspora are heavily influenced by sectarian Hinduism and so energetic sect activities may play a significant role in India and abroad. Diaspora Hindus' considerable financial resources are also a consideration, not simply for religio-political movements, but also for forms of religious practice [5].

Implicit in this article's discussion of the effects of modernization on religious forms is the notion that individuals may use religion as a resource for coping with life's difficulties, including social change. This idea maps onto a line of ethnographic work on how Hindus' sense of well-being may be diminished as globalization expands and potentially creates a disjuncture between Hindus' cultural goals and the material conditions that support those goals [74]. Regardless of whether Hindus participate in congregational forms to attain well-being, it remains to be seen whether the dynamics of Hindu congregational involvement in India are associated with the same increases in life satisfaction as found in other populations and whether similar social processes exist [75]. The impact of Hindu congregational participation on personal well-being (and relatedly, physical and mental health) represents an area in need of both qualitative and quantitative research in the sociology of religion.

More broadly, the information presented here comports with recent arguments from sociologists of religion [17] who contend that investigation of religious practices in increasingly influential nonWestern and principally non-Christian societies will augment our understanding of larger portions of the world's religious life. Moreover, these streams of inquiry will broaden the global applicability of theories in the sociology of religion, thus helping the subdiscipline live up to its name.

\section{Conclusions}

In sum, I have proposed modernization and social networks as two preliminary sources of Hindus' involvement in congregational forms. Modernization subjects people to social change and posese new forms of competition to religion. Due in part to the sorts of social network ties forged or maintained in congregations, congregationally styled religious forms serve as effective buffers to outside competition and social change, including providing receptacles for Hindus experiencing new levels of individual choice in the Indian religious market. In the future, Hindus may increasingly turn to congregational forms to express their religiosity as members of a society in transition.

\section{Acknowledgments}

Thanks to Phillip Connor, Kevin Dougherty, Paul Froese, Stephen Offutt, and Jerry Park for comments on an earlier version of this paper. 


\section{References and Notes}

1. Narayanan, V. Hinduism. The Illustrated Guide to World Religions; Coogan, M., Ed.; Oxford University Press: New York, NY, USA, 1998; pp. 126-161.

2. Narayanan, V. The Hindu Tradition. In World Religions: Eastern Traditions; Oxtoby, W., Ed.; Oxford University Press: New York, NY, USA, 1996; pp. 12-133.

3. Flood, G. An Introduction to Hinduism; Cambridge University Press: New York, NY, USA, 1996.

4. Weightman, S. Hinduism. A New Handbook of Living Religions; Hinnells, J.R., Ed.; Blackwell Publishers: Oxford, UK, 1997; pp. 261-309.

5. Kurien, P.A. A Place at the Multicultural Table: The Development of an American Hinduism; Rutgers University Press: New Brunswick, NJ, USA, 2007.

6. Michaels, A. Hinduism: Past and Present; Princeton University Press: Princeton, NJ, USA, 2004.

7. Lipner, J. Hindus: Their Religious Beliefs and Practices, 2nd ed.; Routledge: New York, NY, USA, 2010.

8. Stark, R.; Hamberg, E.; Miller, A. Exploring Spirituality and Unchurched Religions in America, Sweden, and Japan. J. Contemp. Relig. 2005, 20, 3-23.

9. Roof, W.C. Spiritual Marketplace: Baby Boomers and the Remaking of American Religion; Princeton University Press: Princeton, NJ, USA, 2001.

10. Hout, M.; Fischer, C.S. Why more Americans have no religious preference: Politics and generations. Am. Sociol. Rev. 2002, 67, 165-190.

11. Fuller, R.C. Spiritual, but not Religious: Understanding Unchurched America; Oxford University Press: New York, NY, USA, 2001.

12. Arnett, J.J.; Jensen, L.A. A Congregation of One. J. Adolesc. Res. 2002, 17, 451-467.

13. Stark, R.; Hamberg, E.; Miller, A.S. Exploring spirituality and unchurched religions in America, Sweden, and Japan. J. Contemp. Relig. 2005, 20, 3-23.

14. Davie, G. Religion in Britain since 1945: Believing without belonging; Wiley-Blackwell: Cambridge, MA, USA, 1994.

15. Ammerman, N.T. Everyday Religion: Observing Modern Religious Lives; Oxford University Press: New York, NY, USA, 2007.

16. Norris, P.; Inglehart, R. Sacred and Secular: Religion and Politics Worldwide; Cambridge University Press: New York, NY, USA, 2004.

17. Cadge, W.; Levitt, P.; Smilde, D. De-Centering and Decentering: Thinking Concepts and Methods in the Sociological Study of Religion. J. Sci. Stud. Relig. 2011, 50, 439-447.

18. Stietencron, H. Hinduism: On the proper use of a deceptive term. In Hinduism Reconsidered; Manohar: New Delhi, India, 1989; pp. 11-27.

19. King, U. Some Reflections on Sociological Approaches to the Study of Modern Hinduism. Numen 1989, 36, 72-97.

20. Cohn, B.S. Colonialism and its forms of Knowledge: The British in India; Princeton Univ Press: Princeton, NJ, USA, 1996.

21. King, R. Orientalism and the Modern Myth of "Hinduism". Numen 1999, 46, 146-185.

22. Metcalf, B.D.; Metcalf, T.R. A Concise History of India; Cambridge University Press: New York, NY, USA, 2002. 
23. Shah, A.M. Sects and Hindu Social Structure. Contrib. Indian Sociol. 2006, 40, 209.

24. Madan, T. N. Pathways: Approaches to the Study of Society in India; Oxford University Press: Delhi, India, 1995.

25. Deshpande, S. Modernization. In The Oxford India Companion to Sociology and Social Anthropology; Das, V., Beteille, A., Madan, T.N., Eds.; Oxford University Press: New Delhi, India, 2003; Volume 1, pp. 63-98.

26. Stroope, S. Caste, Class, and Urbanization: The Shaping of Religious Community in Contemporary India. Soc. Indicat. Res. 2011, forthcoming.

27. Kurien, P. "We are better Hindus here:" Religion and ethnicity among Indian Americans. In Religions in Asian America: Building Faith Communities; Min, P.G., Kim, J.H., Eds.; AltaMira Press: Walnut Creek, CA, USA, 2002; Volume 99, p. 120.

28. Vertovec, S. The Hindu Diaspora: Comparative Patterns; Routledge: New York, NY, USA, 2000.

29. Yang, F.; Ebaugh, H.R. Transformations in new immigrant religions and their global implications. Am. Sociol. Rev. 2001, 66, 269-288.

30. Cadge, W.; Ecklund, E.H. Religious service attendance among immigrants. Am. Behav. Sci. 2006, 49, 1574.

31. Bankston, C.; Zhou, M. De facto congregationalism and socioeconomic mobility in Laotian and Vietnamese immigrant communities: A study of religious institutions and economic change. Rev. Relig. Res. 2000, 41, 453-470.

32. Ebaugh, H.R.; Chafetz, J.S. Structural adaptations in immigrant congregations. Sociol. Relig. 2000, 61, 135.

33. Nimbark, A.; Carnes, T.; Yang, F. Paradoxes of Media-Reflected Religiosity among Hindu Indians. In Asian American Religions: the Making and Remaking of Borders and Boundaries; New York University Press: New York, NY, USA, 2004; pp. 98-111.

34. Park, J.Z.; Ecklund, E.H. Negotiating Continuity: Family and Religious Socialization for SecondGeneration Asian Americans. Sociol. Q. 2007, 48, 93-118.

35. Levitt, P.; Bammer, G.; Smithson, M.; Brown, L.D.; Baker, W.F.; O’Malley, M.; Fremont-Smith, M.R.; Skocpol, T.; Liazos, A.; Ganz, M.; et al. Good Needs No Passport: How Immigrants are Changing the American Religious Landscape; The New York Press: New York, NY, USA, 2007.

36. Stroope, S. A Place at the Multicultural Table: The Development of an American Hinduism. Rev. Relig. Res. 2011, 52, 338-339.

37. Hertel, B.R. Church, Sect, and Congregation in Hinduism: An Examination of Social Structure and Religious Authority. J. Sci. Stud. Relig. 1977, 16, 15-26.

38. Chaves, M. Religious Organizations. Am. Behav. Sci. 2002, 45, 1523.

39. Singer, M.B. When a Great Tradition Modernizes: An Anthropological Approach to Indian Civilization; Praeger Publishers: New York, NY, USA, 1972.

40. Srinivas, M.N. Social Change in Modern India; Orient Longman: New Delhi, India, 2004.

41. Sinha, V. Problematizing Received Categories. Curr. Sociol. 2006, 54, 98 -111.

42. Srinivas, M. Religion and Society among the Coorgs of South India; Asia Pub. House: New York, NY, USA, 1965. 
43. Omvedt, G. Dalit Visions: The Anti-Caste Movement and the Construction of an Indian Identity, 2nd ed.; Orient Longman: Hyderabad, India, 2006.

44. Berger, P.L. The Heretical Imperative: Contemporary Possibilities of Religious Affirmation; Anchor Press Garden City: New York, NY, USA, 1979.

45. Bush, E.L. Measuring Religion in Global Civil Society. Soc. Forces 2007, 85, 1645-1665.

46. Tschannen, O. The Secularization Paradigm: A Systematization. J. Sci. Stud. Relig. 1991, 30, 395-415.

47. Casanova, J. Public Religions in the Modern World; University Of Chicago Press: Chicago, IL, USA, 1994.

48. Smith, B.; Froese, P. The Sociology of Buddhism: Theoretical Implications of Current Scholarship. Int. J. Res. Relig. 2008, 4, 1-24.

49. Yamane, D. Secularization on Trial: In Defense of a Neosecularization Paradigm. J. Sci. Stud. Relig. 1997, 36, 109-122.

50. Babb, L. A. Redemptive Encounters: Three Modern Styles in the Hindu Tradition; University of California Press: Berkeley, CA, USA, 1986.

51. Burger, M. What price salvation? The exchange of salvation goods between India and the West. Soc. Compass 2006, 53, 81.

52. Warrier, M. Guru choice and spiritual seeking in contemporary India. Int. J. Hindu Stud. 2003, 7, 31-54.

53. Sharot, S. Beyond Christianity: A Critique of the Rational Choice Theory of Religion from a Weberian and Comparative Religions Perspective. Sociol. Relig. 2002, 63, 427-454.

54. Kurien, P. Religion, Ethnicity and Politics: Hindu and Muslim Indian Immigrants in the United States. Ethnic Racial Stud. 2001, 24, 263-293.

55. Finke, R. Innovative Returns to Tradition: Using Core Teachings as the Foundation for Innovative Accommodation. J. Sci. Stud. Relig. 2004, 43, 19-34.

56. Ebaugh, H.R.; Curry, M. Fictive Kin as Social Capital in New Immigrant Communities. Sociol. Perspect. 2000, 43, 189-209.

57. Krause, N.M. Aging in the Church: How Social Relationships Affect Health; Templeton Press: West Conshohocken, PA, USA, 2008.

58. Lofland, J.; Stark, R. Becoming a World-Saver: A Theory of Conversion to a Deviant Perspective. Am. Sociol. Rev. 1965, 30, 862-875.

59. Snow, D.A.; Zurcher, L.A. Sheldon Ekland-Olson Social Networks and Social Movements: A Microstructural Approach to Differential Recruitment. Am. Sociol. Rev. 1980, 45, 787-801.

60. Stark, R.; Bainbridge, W.S. Networks of Faith: Interpersonal Bonds and Recruitment to Cults and Sects. Am. J. Sociol. 1980, 85, 1376-1395.

61. Stroope, S. Social Networks and Religion: The Role of Congregational Social Embeddedness in Religious Belief and Practice. Sociol. Relig. 2011, forthcoming.

62. Sherkat, D.E. Embedding Religious Choices: Preferences and Social Constraints into Rational Choice Theories of Religious Behavior. In Rational Choice Theory and Religion: Summary and Assessment; Young, L.A., Ed.; Routledge: New York, NY, USA, 1997; pp. 66-86.

63. Ellison, C.G.; Sherkat, D.E. The "Semi-involuntary Institution" Revisited: Regional Variations in Church Participation among Black Americans. Soc. Forces 1995, 73, 1415-1437. 
64. Sherkat, D.E.; Wilson, J. Preferences, constraints, and choices in religious markets: An examination of religious switching and apostasy. Soc. Forces 1995, 73, 993-1026.

65. Iannaccone, L.R. Risk, rationality, and religious portfolios. Econ. Inq. 1995, 33, 285-295.

66. Harriss, B. The Intrafamily Distribution of Hunger in South Asia. In The Political Economy of Hunger: Volume 1: Entitlement and Well-Being; Drèze, J., Sen, A., Eds.; Oxford University Press: New York, NY, USA, 1990; pp. 351-424.

67. Appadurai, A. Gastro-Politics in Hindu South Asia. Am. Ethnol. 1981, 8, 494-511.

68. Hall, P.A.; Lamont, M. Successful Societies: How Institutions and Culture Affect Health; Cambridge University Press: New York, NY, USA, 2009.

69. Frykenberg, R.E. The Emergence of Modern "Hinduism" as a Concept and as an Institution: A Reappraisal with Special Reference to South India. In Hinduism Reconsidered; Manohar: New Delhi, India, 1989; pp. 82-107.

70. Warrier, M. Hindu Selves in a Modern World: Guru Faith in the Mata Amritanandamayi Mission; Routledge: New York, NY, USA, 2005.

71. Qayum, S.; Ray, R. Grappling with Modernity. Ethnography 2003, 4, 520.

72. Stroope, S. How Culture Shapes Community: Bible Belief, Theological Unity, and a Sense of Belonging in Religious Congregations. Sociol. Q. 2011, 52, 568-592.

73. Stroope, S. Education and Religion: Individual, Congregational, and Cross-Level Interaction Effects on Biblical Literalism. Soc. Sci. Res. 2011, 40, 1478-1493.

74. Steve, D. Well-being: Lessons from india. In Pursuits of Happiness: Well-Being in Anthropological Perspective; Mathews, G., Izquierdo, C., Eds.; Berghahn Books: New York, NY, USA, 2009; pp. 127-146.

75. Lim, C.; Putnam, R.D. Religion, Social Networks, and Life Satisfaction. Am. Sociol. Rev. 2010, 75, 914-933.

(C) 2011 by the authors; licensee MDPI, Basel, Switzerland. This article is an open access article distributed under the terms and conditions of the Creative Commons Attribution license (http://creativecommons.org/licenses/by/3.0/). 